\title{
Myotonic dystrophy type 1 presenting with grip myotonia and functional improvement after rehabilitation
}

\author{
Hirohisa Fujikawa (ㄷ, ${ }^{1,2}$ Daigo Hayashi, ${ }^{2}$ Minoru Saito ${ }^{2}$
}

'Department of Medical

Education Studies, International Research Center for Medical Education, Graduate School of Medicine, The University of Tokyo, Bunkyo-ku, Tokyo, Japan ${ }^{2}$ Department of Internal Medicine, Suwa Central Hospital, Chino, Nagano, Japan

\section{Correspondence to} Dr Hirohisa Fujikawa; hirohisa.fujikawa@gmail.com

Accepted 29 March 2021

\section{DESCRIPTION}

Myotonic dystrophy type 1 (DM1) is an autosomal dominant myopathic CTG triplet repeat disorder that affects the muscles, eyes, heart, endocrine system and central nervous system. DM1 can be broadly classified into at least four subtypes based on the patient's clinical presentation: congenital, childhood-onset, adult-onset and late-onset. ${ }^{1}$ Adult-onset DM1 is the most prevalent, characterised by distal muscle weakness, whereas childhood-onset DM1 is frequently overlooked in affected children or adolescents due to the unnoticeable muscular problems. ${ }^{2}$ As muscle involvement may be initially minimal, children often present with difficulty in learning and socialisation at school. ${ }^{34}$ Patients with childhood-onset DM1 develop muscular symptoms at an older age.

Myotonia is defined as delayed muscle relaxation after voluntary contraction, including eye closure, grip or muscle percussion. The presence of grip myotonia, which indicates DM1, notably narrows the differential diagnosis to only a few diseases, such as myotonia congenita, DM or other rare channelopathies. ${ }^{5}$ Here, we present a case

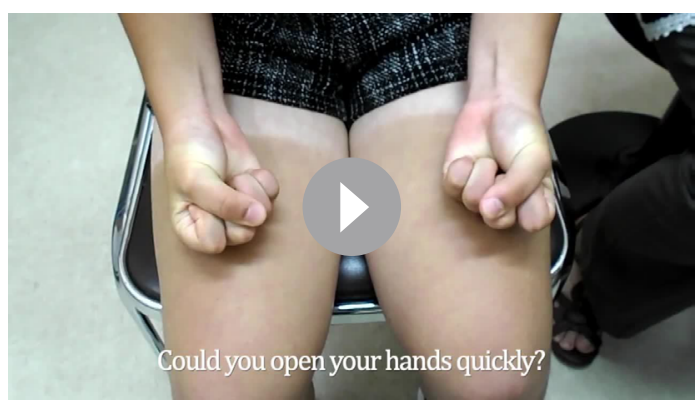

Video 1 Grip myotonia at diagnosis (in about $9 \mathrm{~s}$ of this video).

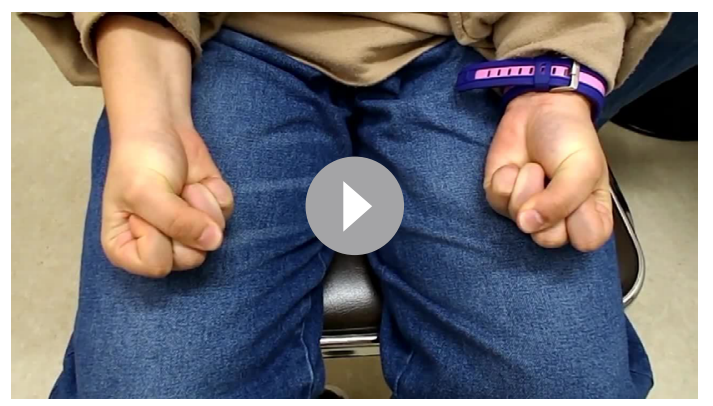

Video 2 Grip myotonia slightly improved with rehabilitation 2 years after the diagnosis (in about $8 \mathrm{~s}$ of this video). of childhood-onset DM1 with a typical clinical course, including the presence of myotonia, which improved with rehabilitation.

A 15-year-old girl presented to our hospital with difficulty in opening her hands after grasping; this was considered abnormal in school medical check-up result. A detailed study of the patient's history revealed that she had been diagnosed with intellectual disability when in elementary school and that she had been aware of the difficulty in opening her hands since junior high school. Physical examination showed grip myotonia (video 1), whereas laboratory findings revealed an elevated creatine phosphokinase level of 513 U/L (nondisease associated range, 24-195 U/L). Electromyography demonstrated myotonic discharges and short-duration low-amplitude motor unit potentials. Based on the typical clinical course described above, DM1 was suspected.

Although DM1 is inherited in an autosomal dominant manner, the family history may be unclear. ${ }^{1}$ The diagnosis of DM1 is confirmed by molecular genetic testing of DM protein kinase $(D M P K) .{ }^{1}$ In the present case, although her family history was unclear, the patient was diagnosed with DM1 based on the confirmed presence of expanded CTG repeat sequences $(600$, non-disease associated range $<35$ ) (Southern blot hybridisation of restriction digested genomic blood DNA).

Although there is currently no established therapy for DM1, symptomatic therapy and monitoring of expected complications can improve the quality of life. According to the recent guideline, children with DM1 should frequently be evaluated for physical, occupational and speech rehabilitation needs. ${ }^{6}$ Although mexiletine is a therapy option for myotonia, it is commonly mild to moderate in patients with DM1 and rarely requires treatment. ${ }^{16}$ In the present case, we did not use any drugs, including mexiletine. Two years of physical and occupational rehabilitation improved the function of her hands (eg, the patient was able to button more easily than before), and physical examination revealed some improvement in grip myotonia (video 2). Regular follow-up showed no signs of

\section{Patient's perspective}

I have suffered a lot in the past, but I felt so relieved to know that it was all because of my illness. Thanks to the rehabilitation, I am now able to perform various activities of daily living. 


\section{Learning points}

Grip myotonia is a key diagnostic sign for myotonic dystrophy type 1 (DM1).

- Childhood-onset DM1 is often missed due to the absence of muscle problems. Patients usually present with low intelligence and other psychosocial problems.

- Although no disease-modifying therapy currently exists, rehabilitation can improve the muscle function and quality of life.

critical complications (eg, cardiac arrhythmia, cataract and diabetes mellitus).

In conclusion, clinicians should be aware that childhood-onset DM1 has long been neglected and DM1 is possible in the differential diagnosis of childhood learning difficulty and muscular symptoms. Rehabilitation may improve the function of hands.

Contributors HF: Drafted the manuscript. DH and MS: Reviewed and supervised the manuscript.
Funding The authors have not declared a specific grant for this research from any funding agency in the public, commercial or not-for-profit sectors.

Competing interests None declared.

Patient consent for publication Obtained.

Provenance and peer review Not commissioned; externally peer-reviewed.

\section{ORCID iD}

Hirohisa Fujikawa http://orcid.org/0000-0002-8195-1267

\section{REFERENCES}

1 Turner C, Hilton-Jones D. The myotonic dystrophies: diagnosis and management. J Neurol Neurosurg Psychiatry 2010;81:358-67.

2 Ho G, Cardamone M, Farrar M. Congenital and childhood myotonic dystrophy: current aspects of disease and future directions. World J Clin Pediatr 2015;4:66-80.

3 Echenne B, Rideau A, Roubertie A, et al. Myotonic dystrophy type I in childhood long-term evolution in patients surviving the neonatal period. Eur J Paediatr Neurol 2008;12:210-23.

4 Angeard N, Jacquette A, Gargiulo M, et al. A new window on neurocognitive dysfunction in the childhood form of myotonic dystrophy type 1 (DM1). Neuromuscul Disord 2011:21:468-76.

5 Miller TM. Differential diagnosis of myotonic disorders. Muscle Nerve 2008;37:293-9.

6 Johnson NE, Aldana EZ, Angeard N, et al. Consensus-based care recommendations for congenital and childhood-onset myotonic dystrophy type 1. Neurol Clin Pract 2019;9:443-54.

Copyright 2021 BMJ Publishing Group. All rights reserved. For permission to reuse any of this content visit https://www.bmj.com/company/products-services/rights-and-licensing/permissions/

BMJ Case Report Fellows may re-use this article for personal use and teaching without any further permission.

Become a Fellow of BMJ Case Reports today and you can:

- Submit as many cases as you like

- Enjoy fast sympathetic peer review and rapid publication of accepted articles

- Access all the published articles

- Re-use any of the published material for personal use and teaching without further permission

\section{Customer Service}

If you have any further queries about your subscription, please contact our customer services team on +44 (0) 2071111105 or via email at support@bmj.com.

Visit casereports.bmj.com for more articles like this and to become a Fellow 